\title{
n-Alkan-2-one biomarkers as a proxy for palaeoclimate reconstruction in the Mfabeni fen, South Africa
}

Andrea Baker, J oyanto Routh and Alakendra N. Roychoudhury

The self-archived postprint version of this journal article is available at Linköping University Institutional Repository (DiVA):

http:/ / urn.kb.se/ resolve?urn=urn:nbn:se:liu:diva- 148375

N.B.: When citing this work, cite the original publication.

Baker, A., Routh, J., Roychoudhury, A. N., (2018), n-Alkan-2-one biomarkers as a proxy for palaeoclimate reconstruction in the Mfabeni fen, South Africa, Organic Geochemistry, 120, 75-85. https:// doi.org/ 10.1016/j.orggeochem.2018.03.001

Original publication available at:

https:// doi.org/ 10.1016/j.orggeochem.2018.03.001

Copyright: Elsevier

http:// www.elsevier.com/

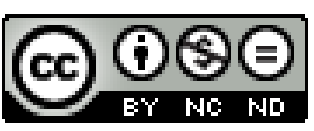




\title{
n-Alkan-2-one biomarkers as a proxy for palaeoclimate reconstruction
} in the Mfabeni fen, South Africa

\author{
Andrea Baker ${ }^{*}$, Joyanto Routh ${ }^{b}$, Alakendra N. Roychoudhurya \\ aDepartment of Earth Sciences, Stellenbosch University, Stellenbosch, South Africa \\ bDepartment of Thematic Studies - Environmental Change, Linköping University,58183 \\ Linköping, Sweden
}

\section{Abstract}

The sub-tropical Mfabeni fen is the only continuous coastal peat deposit that documents glacial and interglacial palaeoenvironmental conditions since the late Pleistocene (ca. 47 cal kyr BP) in southern Africa. Published bulk geochemical, biomarker and leaf wax $\delta^{13} \mathrm{C}$ data, along with palynology and stratigraphic studies of the Mfabeni peat sequence, renders it an ideal record for testing new palaeoreconstruction proxies. In this study, we aimed to establish the proxy potential of $n$-alkan-2-one ( $n$-ket) compounds by tracing their source/origin, post-depositional diagenetic changes and if they preserve a robust palaeoenvironment signal that complements our understanding of palaeoclimatic variations. In the Mfabeni archive the most likely source for $n$-kets is via microbial decarboxylation of $n+1$-alkanoic acids ( $n$-FAs) and, to a lesser degree, oxidation of same chain length $n$-alkanes ( $n$-alks). The $n$-ket average chain length (ACLket) and $n$ - $\mathrm{C}_{23}$ and $\mathrm{C}_{25}$ ket / precursor ratios display a statistical significant negative relationship with the $n$ alk aquatic plant proxy $\left(\mathrm{P}_{\mathrm{aq}}\right)$, suggesting the source of $n$-kets to be submerged aquatic plants during waterlogged conditions that suppressed microbial activity during the ensuing anoxic conditions. Both the mid-chain and long-chain $n$-ket/precursor ratios display predominant water level fluctuation controls, with temperature as a secondary regulator. By comparing the $n$-ket data with published environmental and climate reconstructions from the same core, and geomorphology and palynological studies of the Mfabeni basin, we 
conclude that the $n$-kets show promise as a palaeoclimate proxy and can be used in conjunction with other biomarker proxies to reconstruct ancient hydrological changes in sub-tropical peatlands.

33

34 Key words: $n$-Alkan-2-ones; sub-tropical peat; palaeoenvironment, Late Pleistocene; South 35 Africa.

36

37

38 


\section{Introduction}

Palaeoclimate proxies have inherent limitations due to difficulties in quantifying geochemical relationships in modern systems and distinguishing between preservation and diagenetic changes after deposition (Sageman and Lyons, 2003). Therefore, it is useful to use a multi-proxy approach to reduce uncertainty in palaeoclimate reconstructions by providing improved prognostic data. Consequently, geochemists continually strive to add new and improved proxies to address these inadequacies and to advance understanding about past climate and environmental change archived in sedimentary records.

$n$-Alkan-2-ones ( $n$-kets) are a relatively novel group of biomarkers compared with the more commonly studied straight chain $n$-alkyl lipids, namely $n$-alkanes ( $n$-alks), $n$ alkanoic acids ( $n$-FAs) and $n$-alkanols ( $n$-alcs, e.g. Xie et al., 2008). Even though studies have documented $n$-kets in soils (Huang et al., 1996; van Bergen et al., 1998; Bull et al., 2000; Naafs et al., 2004; Bai et al., 2006), lacustrine sediments (Cranwell et al., 1987; Meyers and Ishiwatari, 1993, Wenchuan et al., 1999), peat basins (Lehtonen and Ketola, 1990, 1993) and contemporary plants (Wenchuan et al., 1999; Baas et al., 2000; Hernandez et al., 2001; Nichols and Huang, 2007; Ortiz et al., 2011), their identification is frequently part of a general characterisation of the wider suite of biomarkers. There has been little assessment of their effectiveness as a palaeoenvironmental proxy. To the authors' knowledge, the only studies dedicated to determining proxy potential of $n$-kets are those from the Hani mire, north eastern China (Zheng et al., 2011a) and Hongyuan peatland on the eastern fringes of the Tibetan Plateau (Zheng et al, 2011b), where $n$-ket data were compared with regional geochemical and palynological studies.

Although some peat forming plants and phytoplankton are reported to contain low concentrations of $n$-kets (Lehtonen and Ketola, 1990; Hernandez et al., 2001; Nichols 
and Huang, 2007; Ortiz et al., 2011), other studies have reported that the principal origin of these biomarkers in sedimentary environments is either microbial oxidation of the same chain length $n$-alk and/or decarboxylation of the $n+1$ FA (Volkman et al., 1983; Bai et al., 2006; Ortiz et al., 2010, 2011). Furthermore, López-Días et al. (2013) reported that distribution patterns of $n$-alks and $n$-kets in the Roñanzas peat bog did not justify a single source, and they therefore suggested an additional secondary source of $n$-kets derived from bacterial input. Regardless, the predominant sources of these biomarkers appear to be governed by enzymatic microbial activity, which is usually linked to temperature (Schmidt et al., 2011).

Peat accumulates when net primary production (NPP) outstrips organic matter (OM) degradation (Chimner and Ewel, 2005). The relatively high ambient temperatures experienced in sub-tropical peatlands are therefore expected to produce an enhanced rate of $\mathrm{OM}$ decay driven by microbial processes. However, anoxic conditions generated by extended waterlogging events retard $\mathrm{OM}$ decomposition and result in peat accumulating in sub-tropical regions (Rieley et al., 1996). Consequently, physical peat forming indices, such as TOC concentrations and accumulation rates (Baker et al., 2014) are useful for measuring the proportion of $\mathrm{OM}$ stored as peat and for providing insight into the palaeoenvironmental conditions prevalent at the time of sedimentation, which are ultimately controlled by climate (Baker et al., 2014, 2016, 2017).

The Mfabeni fen, situated on the south-eastern coastline of Africa (Fig. 1), is an exceptional and continuous record of peat accumulation spanning the last ca. $47 \mathrm{cal} \mathrm{kyr}$ BP. Such rich sedimentary archives are rare in southern Africa due to the overall dry climate and steep topography of the region. Palynological (Finch and Hill, 2008) and geomorphological (Grundling et al., 2013) studies in the fen have been undertaken, and high-resolution bulk geochemical (Baker et al., 2014), biomarker (Baker et al., 2016) and leaf wax ${ }^{13} \mathrm{C}$ isotopic (Baker et al., 2017) investigations have been carried out on the 
same core (SL6), making the Mfabeni peat sequence an ideal archive for assessing the climate proxy value of the $n$-kets during the transition from glacial to postglacial conditions. Because the Mfabeni fen is situated at a relatively low latitude, Finch and Hill (2008) and Baker et al. (2016) both found that the basin experienced subdued temperature fluctuations relative to higher latitudes since the Late Pleistocene. The biomarker (Baker et al., 2016) and leaf wax $\delta^{13} \mathrm{C}$ proxies (Baker et al., 2017) implied that plant OM sources in the Mfabeni were predominantly influenced by water level fluctuation, as opposed to temperature changes in the basin. Ficken et al. (2000) developed the $n$-alk aquatic plant proxy $\left(\mathrm{P}_{\mathrm{aq}}\right)$ on the premise that aquatic plants contributed predominantly mid-chain length $\left(\mathrm{C}_{23}\right.$ and $\left.\mathrm{C}_{25}\right) n$-alks, while emersed and terrestrial plant leaf waxes are dominated by long-chain $\left(\mathrm{C}_{27}-\mathrm{C}_{33}\right)$ homologs. Some of these compounds have been proposed as precursors for $n$-kets and therefore, could help delineate the $n$-ket sources and ultimately the palaeoenvironmental conditions at times of peat deposition. Additionally, microbial respiration, which is the mechanism by which precursors may be converted to $n$-kets can be influenced by several factors besides temperature, including $\mathrm{OM}$ chemistry and reactivity, soil $\mathrm{pH}$, redox conditions and accessibility to potential decomposers (Schmidt et al., 2011). Considering that Mfabeni basin's geomorphology resulted in hydrology being the dominant control on plantderived OM sources and rate of microbial alteration (Grundling et al., 2013, Baker et al., $2016,2017)$, the bimodal distribution of $n$-ket homologues, the concentration correlations between $n$-alks, $n$-FAs and $n$-kets, and the ratios of the respective $n$-kets/nket precursors could help in delineate changes in past water levels, which according to Baker et al. $(2016,2017)$ can be directly linked to regional precipitation and to a lesser degree ambient air temperatures.

In this study, we explore the relationships between $n$-kets and published bulk geochemical and biomarker proxies in Mfabeni core SL6 to assess the potential of $n$-kets 
in reconstructing palaeoenvironmental conditions. This assessment will be done by determining their origin, post-depositional alteration, and by corroborating the $n$-kets data with pollen and stratigraphic records from the Mfabeni fen to establish whether or not a climate signal is preserved in these novel compounds.

\section{Geographical and geological setting}

\subsection{Site description}

The shallow $350 \mathrm{~km}^{2}$ St Lucia Lake dominates the UNESCO World Heritage

iSimangaliso Wetland Park situated on the northern shores of Kwazulu-Natal province, South Africa (Fig. 1). On the eastern shores of the lake, the Mfabeni fen lies within an interdunal valley (Botha and Porat, 2007) at ca. $11 \mathrm{~m}$ a.s.l. (Finch and Hill, 2008) measuring 10 x $3 \mathrm{~km}$ (Clulow et al., 2012; Grundling et al., 2013) and an up to $10.8 \mathrm{~m}$ thick sediment record that accumulated along the M8 transect (Fig. 1, Grundling, 2001; Grundling et al., 2013). The fen's hydrology is dominated by groundwater from the Maputaland aquifer, which is structurally controlled by the north-south aligned coastal dune barrier (Grundling et al., 2013; Taylor et al., 2006a; Venter, 2003), and local precipitation. The area is subject to a sub-tropical climate and experiences mainly austral summer rainfall of between 900 and 1200 mm/yr (Grundling, 2001; Taylor et al., $2006 \mathrm{~b}$ ), with the highest amount of precipitation falling on the sand dune coastal barrier, which is the recharge area of the Maputaland aquifer (Kelbe and Rawlins, 1993). This results in seasonal inundation of the Mfabeni basin during the wetter summer months and groundwater level stabilisation just below or near the soil surface during the drier winter months. No correlation was found by Baker (2016) between peat accumulation in the Mfabeni basin, as measured by TOC concentrations and accumulation rate and regional Late Pleistocene sea level reconstructions done by

140 Ramsay and Cooper (2002). Therefore, sea level has not had a major influence on the fen's hydrology, resulting in a unique coastal peat deposit that owes its longevity and 
continuous accumulation record to the protection against sea level transgressions and

143 the enhanced groundwater transmissibility (Grundling et al., 2013) of the ca. 55 kyr old 144 adjacent coastal dune barrier (Porat and Botha, 2008). The fen forms part of the greater

145 Natal Mire Complex (Fig.1) that extends from southern Mozambique to the south of

146 Richards Bay, Kwazulu-Natal, and was formed via valley infilling within the

147 KwaMbonanbi formation coastal dune depression (Smuts, 1992). The fen vegetation is

148 predominantly herbaceous sedges and grasses (Finch, 2005) that are dominated by

149 Fimbristylis bivalvis, Scleria poiformis, Rhynchospora holoschoenoides, Rhynchospora corymbosa sedges and Panicum glandulopaniculatum, Ischaemum fasciculatum grass species (Venter, 2003, Finch and Hill, 2008, Clulow et al., 2012), and the fen is surrounded by Maputaland wooded grassland, coastal dune and fresh water swamp forests (Mucina et al., 2006). Apart from a general Mfabeni plant community study done by Venter (2003), where she broadly classified 11 fen and 3 swamp forest plant communities grouped according to their habitat existing in and around the basin, indepth records of contemporary Mfabeni plant communities and their lipid characteristics are currently absent in the literature. 


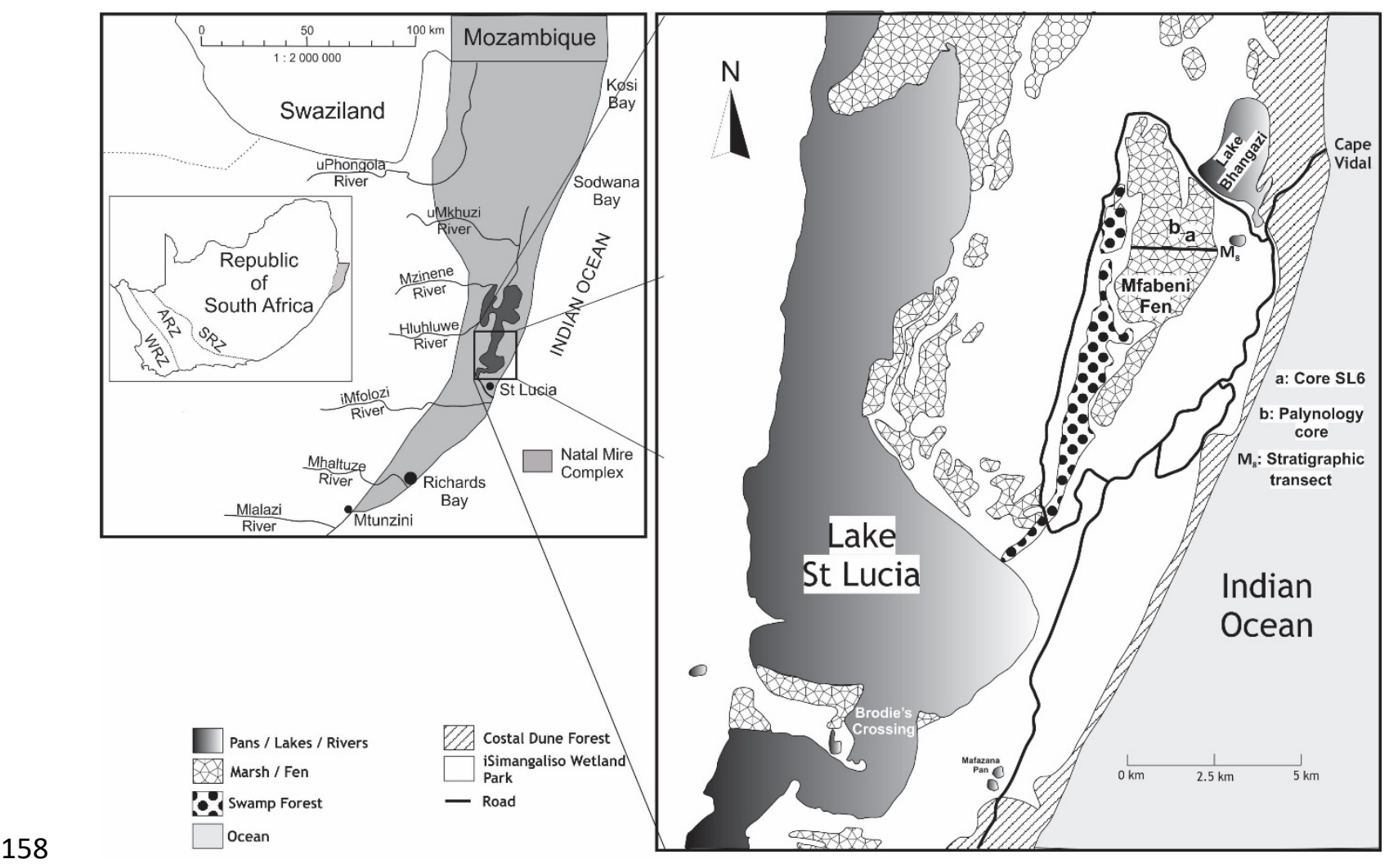

Figure 1: Location of core SL6 (a) in the Mfabeni fen, iSimangoliso Wetland Park, northern Kwazulu-Natal, South Africa. Location of palynology core (b; Finch and Hill, 2008) and most proximal and deepest stratigraphic transect (M8; Grundling et al. 2013) included for orientation. WRZ = winter rainfall zone; ARZ = all-year rainfall zone; SRZ = summer rainfall zone. Modified from Baker et al. (2017).

\subsection{Lithology and age model}

Grundling et al., (2013) published a detailed morphology of the Mfabeni peat basin where they classified up to five distinctive peat packages, evident in transect M8 (Fig. 1) that are occasionally interspersed with thin sandy layers, found mainly in the eastern part of the basin. They suggested the sand packages are of aeolian origin because evidence of fluvial input into the basin is absent. The $810 \mathrm{~cm}$ SL6 core was extracted from the deepest part of the Mfabeni fen $\left(28.15021^{\circ} \mathrm{S} ; 32.52508^{\circ} \mathrm{E}\right)$ in consecutive drives using a Russian peat corer with a sampling barrel measuring $5 \mathrm{~cm}$ x $50 \mathrm{~cm}$. It was catalogued in the field, the lithology described and sliced into $1-2 \mathrm{~cm}$ intervals in the laboratory and then freeze-dried in preparation for geochemical analyses. The core 


\section{Core SL6}

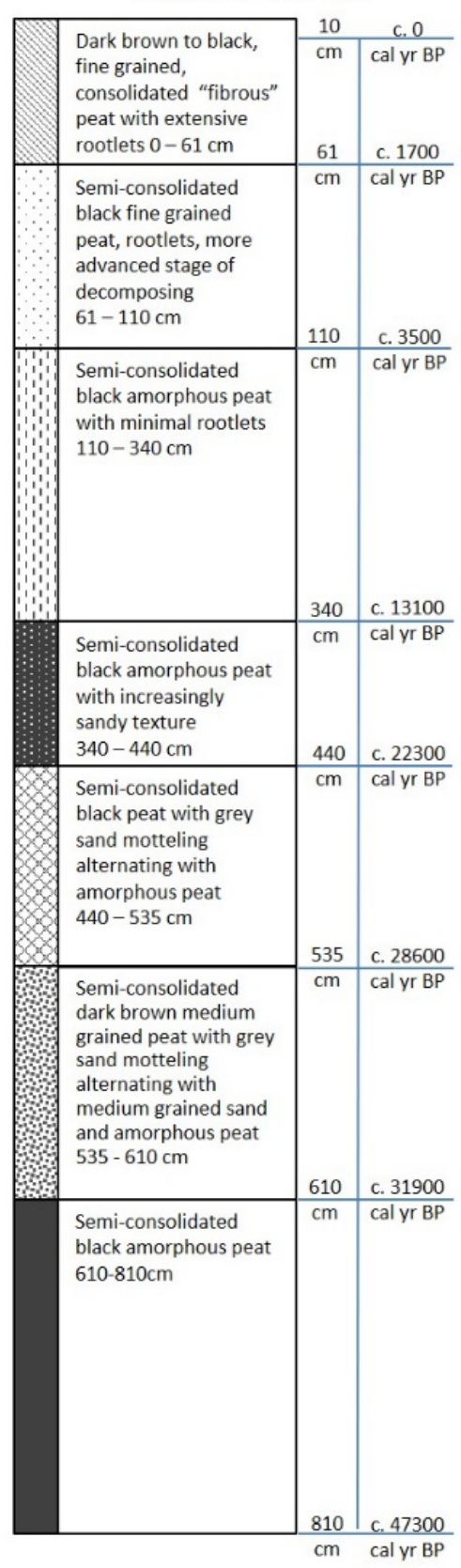

\section{Not to Scale} profile with approximate boundary ages. From Baker et al. (2014).
Nine selected bulk peat samples (at 10, 109, 209, 309, 405, $510,609,709$ and $805 \mathrm{~cm}$ ) were ${ }^{14} \mathrm{C}$ radiocarbon dated and calibrated using the northern hemisphere terrestrial calibration curve IntCal09, with a southern hemisphere offset of $40 \pm 20{ }^{14} \mathrm{C}$ yr. Age values were adjusted using the age-depth Bacon modelling software (Blaauw and Christeny, 2011). For more details see Baker et al. (2014) and references therein.

\section{Methodology}

A modified lipid extraction was done according to

Wakeham et al. (2002) on 36 selected core intervals that were analysed for $n$-alks, $n$-FAs and $n$-alcs (see Baker et al., 2016 and references therein) and $n$-kets. 2g Freezedried sediment samples were extracted in a Dionex automated solvent extractor with dichloromethane $(\mathrm{DCM}) / \mathrm{MeOH}(9: 1 \mathrm{v} / \mathrm{v})$. An aliquot of the total lipid extract (TLE) was saponified with $0.5 \mathrm{~N} \mathrm{KOH}$ (in $\mathrm{MeOH}$ ) at $100{ }^{\circ} \mathrm{C}$ for $2 \mathrm{hr}$; then $5 \% \mathrm{NaCl}$ was added and the mixture agitated and washed with hexane to separate the neutral (TLE-N) and acidic (TLE-A) fractions. The TLE-N fraction was introduced into a silica gel column and the $n$-alk (F1) fraction eluted with $10 \mathrm{ml}$ hexane and then $5 \mathrm{ml}$ of $25 \%$ 
aliquots of increasing proportions of EtOAc in hexane (5\%:95\%; 10\%:90\%;15\%:85\% and 20\%:80\%). The condensed F2 fraction was then derivatized with N,Obis(trimethylsilyl)trifluoroacetamide (BSTFA) and pyridine at $70{ }^{\circ} \mathrm{C}$ for $2 \mathrm{hr}$. The TLEA fraction was acidified using $6 \mathrm{~N}$ HCL, extracted in hexane and methylated with $\mathrm{BF}_{3}$ in methanol to isolate the methyl ester bound FAs. The samples were injected via splitless mode into an Agilent 6890 gas chromatograph (GC) interfaced to a 5973 MSD mass spectrometer (MS) with a DB-5 (5\% phenyl, 95\% dimethyl polysiloxane) fused silica column (30 m x $0.25 \mathrm{~mm}$ i.d. x $0.25 \mu \mathrm{m}$ film thickness). See Baker et al. (2016) for GC and MS operating parameters. Biomarker concentrations are reported in ng/mg TOC.

\section{Results and discussion}

\subsection{Interpreting biomarker trends}

While Nichols and Huang (2007) found evidence of $n$-kets only in modern peatland Sphagnum species sampled across the Midwest and New York state in north America, Ortiz et al. (2011) recorded low concentrations of $n$-kets in both Sphagnum (maximized at $\mathrm{C}_{23}$ ) and other peat forming plants in the Roñanzas bog. They documented high molecular weight $n$-ket homologues in terrestrial plants, more specifically sedge and grass species with predominant $\mathrm{C}_{27}$ and $\mathrm{C}_{31} n$-alks, $\mathrm{C}_{29}$ and $\mathrm{C}_{31} n$-kets and $\mathrm{C}_{22}$ and $\mathrm{C}_{24}$ $n$-FAs, respectively. In the Mfabeni record, the $n$-ket homologues display predominant bimodal distributions (Fig. 3) with a prevalence for both mid- and long-chain compounds with odd / even predominances, and maxima dominated by $n-\mathrm{C}_{33}(30 \%)$ and $n$ - $\mathrm{C}_{23}(43 \%)$. Both $n$-ket/FA and $n$-ket/alk precursor ratios exhibited varying degrees of similarity between different chain lengths (e.g. $n$ - $\mathrm{C}_{25}$ ket / $\mathrm{C}_{25}$ alk and $\mathrm{C}_{27}$ ket / $\mathrm{C}_{27}$ alk) and precursor combinations (e.g. $n$ - $\mathrm{C}_{25}$ ket / $\mathrm{C}_{26} \mathrm{FA}$ and $\mathrm{C}_{25}$ ket / $\mathrm{C}_{25}$ alk, Table 1). The $n$ - $\mathrm{C}_{25}$ to $n$ - $\mathrm{C}_{29}$ odd ket/FA precursor ratios range between $5.0 \times 10^{-4}$ and $6.4 \times 10^{-2}$, whereas $n$ $\mathrm{C}_{31} \mathrm{ket} / n-\mathrm{C}_{32} \mathrm{FA}$ precursor ratio display a minimum of $1.3 \times 10^{-2}$ (ca. $39.5 \mathrm{cal} \mathrm{kyr} \mathrm{BP}$ ) and 
226 a maximum 0.5 (ca. 8.0 cal kyr BP; Fig. 4). In contrast, the $\mathrm{C}_{23}$ and $\mathrm{C}_{25}$ ket/alk

227 precursor ratios range between $2.9 \times 10^{-4}$ (ca. 0.0 cal kyr BP) and 0.3 (ca. 1.5 cal kyr BP),

228 while $n$ - $\mathrm{C}_{31} \mathrm{ket} / \mathrm{n}$ - $\mathrm{C}_{31}$ alk display a maximum of 0.2 (ca. $8.0 \mathrm{cal} \mathrm{kyr} \mathrm{BP}$ ) and a minimum

229 of $2.0 \times 10^{-3}(0.0 \mathrm{kcal}$ yr BP; Fig. 4). The $n$-ket average chain length values (ACLket; Fig.

230 4) have a variable distribution, maximising at 31.7 (ca. 27.4 cal kyr BP) and minimizing

231 at 23.0 (ca. 14.8 cal kyr BP). 

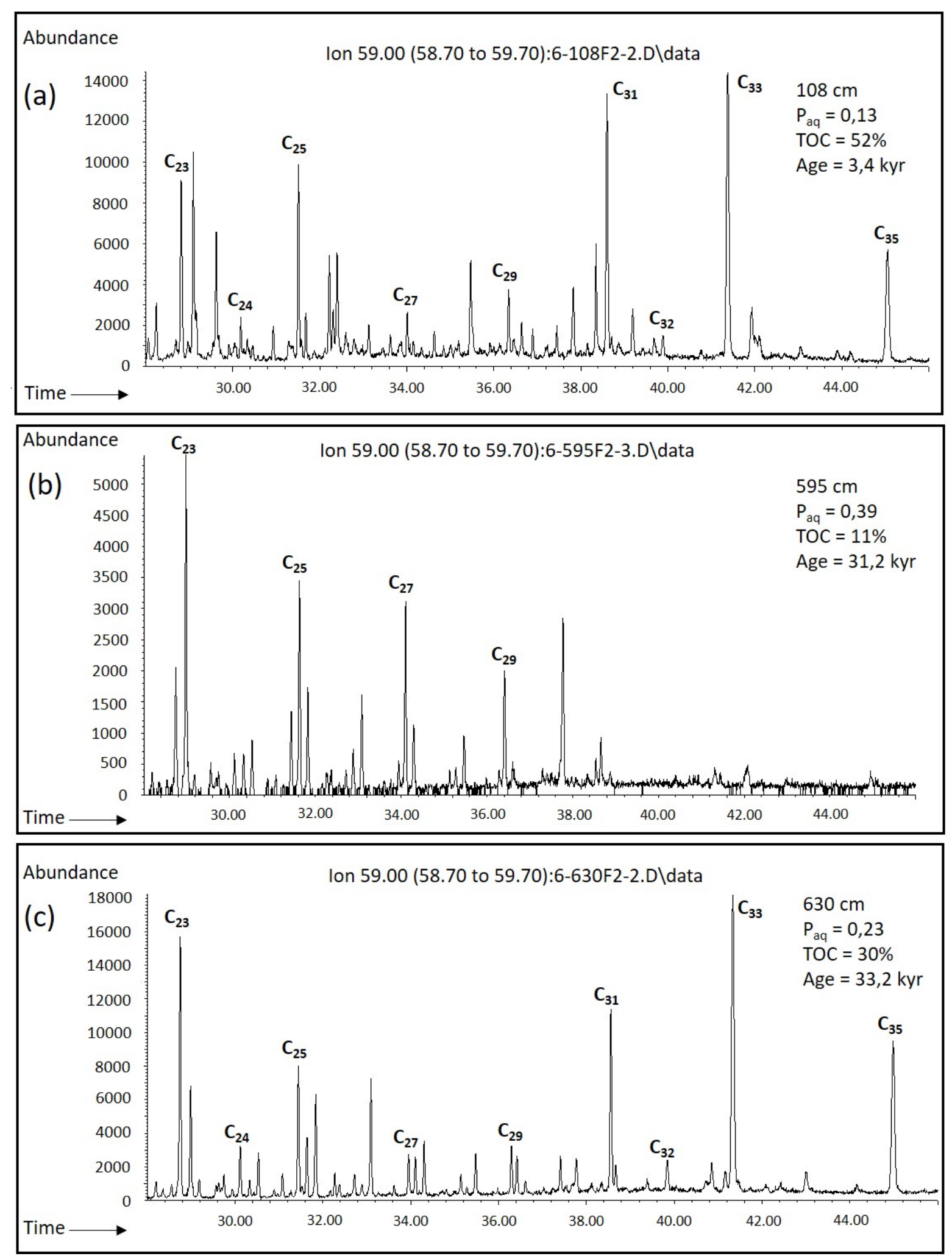

Figure 3: $n$-alkan-2-one distributions $(\mathrm{m} / \mathrm{z}=59)$ of selected peat intervals from the Mfabeni fen. Depth, $n$ alkane aquatic plant ratio $\left(\mathrm{P}_{\mathrm{aq}}\right)$, TOC concentrations and age (cal kyr BP) of sample included for

235 comparison. 


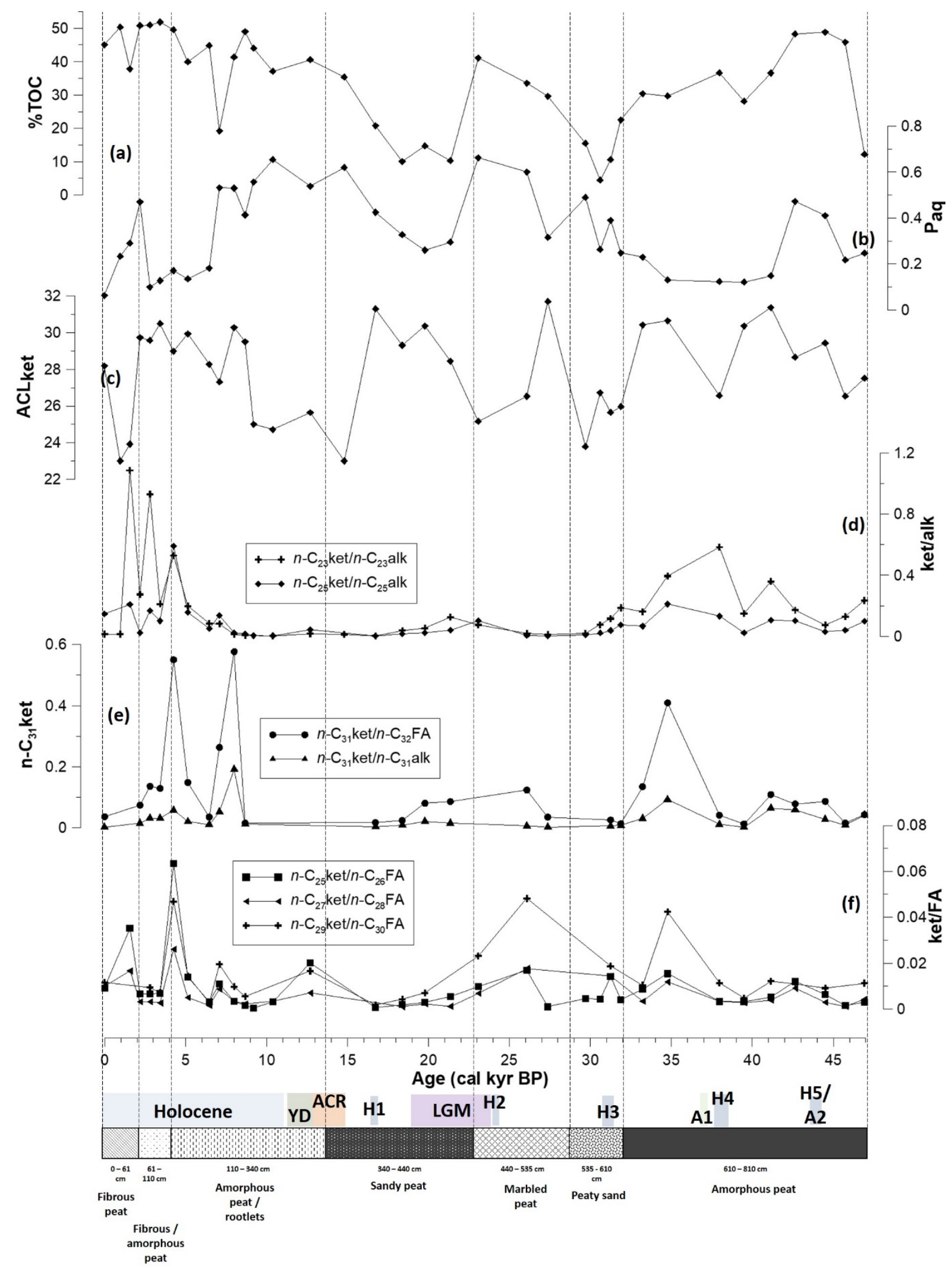

Figure. 4. $n$-Alkan-2-one and precursor $n$-alkane and $n$-alkanoic acid proxy comparisons in core SL6. (a) \%TOC; Baker et al. (2014), (b) aquatic $n$-alkane proxy ( $\mathrm{P}_{\text {aq }}$; Baker et al., 2016), (c) $n$-alkan-2-one average chain length (ACLket), (d) $\mathrm{C}_{23}$ and $\mathrm{C}_{25} n$-alkan-2-one/n-alkane precursor ratios, (e) $\mathrm{C}_{31} n$-alkane-2-one/nalkane and $n$-alkanoic acid precursor ratios, (f) $n-\mathrm{C}_{25}, \mathrm{C}_{27}$ and $\mathrm{C}_{29} / \mathrm{n}$-alkanoic acid precursor ratios. $\mathrm{H} 1-5$. Heinrich events (dates from Hemming, 2004); A1 and A2. Antarctic warming events (Blunier et al., 1998; 
Stocker, 2000); Last Glacial Maximum (LGM); Antarctic cold reversal (ACR); Younger Dryas (YD); Holocene (Hol).

Table 1: Statistical relations between biomarker concentrations and proxy ratios in Core SL6. (One tail test; P, probability level; df, degrees of freedom; $\boldsymbol{n}$-alkane, $\boldsymbol{n}$-alkanoic acid and $\boldsymbol{n}$ alkanol data previously published by Baker et al., 2016).

\begin{tabular}{|c|c|c|c|c|}
\hline & $\begin{array}{c}\text { Alk ng/mg TOC } \\
\text { vs } \\
\text { FA ng/mg TOC }\end{array}$ & $\begin{array}{c}\text { FA ng/mg TOC } \\
\text { vs } \\
\text { Alc ng/mg TOC }\end{array}$ & $\begin{array}{c}\text { Alk ng/mg TOC } \\
\text { vs } \\
\text { Ket ng/mg TOC }\end{array}$ & $\begin{array}{c}\text { FA ng/mg TOC } \\
\text { vs } \\
\text { Ket ng/mg TOC }\end{array}$ \\
\hline$r$ & 0,56 & 0,41 & \multirow[t]{2}{*}{0,28} & 0,44 \\
\hline$P=0.01$ & Sig & Sig & & Sig \\
\hline \multirow[t]{3}{*}{$P=0.05$} & Sig & Sig & Sig & Sig \\
\hline & $d f=34$ & $d f=34$ & $d f=34$ & $d f=34$ \\
\hline & $\begin{array}{c}n-\mathrm{C}_{23} \text { ket / } n-\mathrm{C}_{23} \text { alk vs } \\
\text { vs } \\
n-\mathrm{C}_{23} \text { ket / } n-\mathrm{C}_{24} \mathrm{FA}\end{array}$ & $\begin{array}{c}n-C_{25} \text { ket / } n-C_{25} \text { alk } \\
\text { vs } \\
n-C_{25} \text { ket / } n-C_{26} \text { FA }\end{array}$ & $\begin{array}{c}n-C_{27} \text { ket } / n-C_{27} \text { alk } \\
\text { vs } \\
n-C_{27} \text { ket } / n-C_{28} \text { FA }\end{array}$ & $\begin{array}{c}n-\mathrm{C}_{29} \text { ket / } n-\mathrm{C}_{29} \text { alk } \\
\text { vs } \\
n-\mathrm{C}_{29} \text { ket / } n-\mathrm{C}_{30} \text { FA }\end{array}$ \\
\hline r & 0,61 & 0,86 & 0,49 & \multirow[t]{2}{*}{0,38} \\
\hline$P=0.01$ & Sig & Sig & Sig & \\
\hline \multirow[t]{4}{*}{$P=0.05$} & Sig & Sig & Sig & Sig \\
\hline & $d f=34$ & $d f=34$ & $d f=34$ & $d f=34$ \\
\hline & $\begin{array}{c}n-C_{31} \text { ket } / n-C_{31} \text { alk } \\
\text { vs }\end{array}$ & $\begin{array}{c}\mathrm{ACL}_{\text {ket }} \\
\text { vs }\end{array}$ & $\begin{array}{c}n-C_{23} \text { ket } / n-C_{23} \text { alk } \\
\text { vs }\end{array}$ & $\begin{array}{c}n-C_{25} \text { ket } / n-C_{25} \text { alk } \\
\text { vs }\end{array}$ \\
\hline & $n-C_{31}$ ket / n- $C_{32}$ FA & $\mathbf{P}_{\mathrm{aq}}$ & $\mathbf{P}_{\mathrm{aq}}$ & $\mathbf{P}_{\mathrm{aq}}$ \\
\hline$r$ & 0,82 & $-0,43$ & $-0,43$ & $-0,40$ \\
\hline$P=0.01$ & Sig & Sig & Sig & Sig \\
\hline \multirow[t]{2}{*}{$P=0.05$} & Sig & Sig & Sig & Sig \\
\hline & $d f=34$ & $d f=34$ & $d f=34$ & $d f=34$ \\
\hline
\end{tabular}

When comparing the trends for total concentrations of $n$-kets in core SL6 (Table 1) with $n$-alks, $n$-FAs and $n$-alcs published by Baker et al. (2016), $n$-alks vs. $n$-FAs $(\mathrm{r}=0.56, \mathrm{P}=$ $0.01, \mathrm{df}=34)$ and $n$-FAs vs. $n$-alcs $(\mathrm{r}=0.41, \mathrm{P}=0.01, \mathrm{df}=34)$ show significant positive correlations. These statistical relations suggest that $n$-alks, $n$-FAs and $n$-alcs share a common source (i.e. plant-derived OM). However, Baker et al. (2016) did conclude that a proportion of the $n$-FAs in core SL6 could have been derived from secondary microbial origin via the conversion of primary plant acids produced by OM decomposers. $n$-Alks and $n$-FAs display lower r values but still significant positive correlations with $n$-kets (r $=0.28, \mathrm{P}=0.05, \mathrm{df}=34$ and $\mathrm{r}=0.44, \mathrm{P}=0.01, \mathrm{df}=34$, respectively), implying the $n$ - 
kets in the Mfabeni fen are more likely a product of microbial reworking of their $n+1$-FA precursors and to a lesser extent, from $n$-alks, in view of the more recalcitrant nature of the latter (Meyers and Ishiwatari, 1993). This possibility is consistent with the origin of these compounds proposed by Zheng et al. (2011b) for the Hongyuan peat basin, which is under the influence of both the East Asian and Indian summer monsoon systems and so subject to fluctuating precipitation levels, similar to the Mfabeni fen (Baker et al., 2014, 2016). The correlation coefficients for $n$-kets vs. $n$-alks $(\mathrm{r}=0.28)$ and $n$-kets vs. $n$-FAs $(\mathrm{r}$ $=0.44)$ are however relatively low, suggesting an additional process contributed to the origins of the Mfabeni $n$-kets. As reported by Ortiz et al. (2011), terrestrial peat forming plants in the Roñanzas bog contain low concentrations of long chain $n$-kets, leading us to consider that direct input from vegetation, although at lower concentrations than microbial sources, could also be a source for high molecular weight $n$-ket homologues (Fig. 3) found in the Mfabeni peat record. Consistent with this hypothesis, graminoids, the dominant plant species found in the basin today, are characterised by predominant $\mathrm{C}_{29}$ to $\mathrm{C}_{35}$ lipid homologues (Jaffé et al., 2001; Mead et al., 2005). On analysis of the homologue distributions in conjunction with the biomarker proxies, the samples with a strong bimodal $\mathrm{C}_{23}$ and $\mathrm{C}_{33}$ distribution display emersed / mixed source $\mathrm{P}_{\text {aq }}$ values (Fig. $\left.3 c, \mathrm{P}_{\mathrm{aq}}=0.23\right)$, while the other two end members exhibit maxima at $\mathrm{C}_{33}$ with a $\mathrm{P}_{\mathrm{aq}}$ value indicating a terrestrial source $\left(\mathrm{P}_{\mathrm{aq}}=0.13\right.$, Fig $\left.3 \mathrm{a}\right)$ or $\mathrm{C}_{23}$ with an aquatic plant signature $\left(\mathrm{P}_{\mathrm{aq}}=0.39\right.$, Fig $\left.3 \mathrm{~b}\right)$. This analysis confirms the source of $n$-kets in the Mfabeni record is governed by the input of plant lipids, either via direct input or conversion of primary lipids by microbial organisms. Besides the relatively low direct input of $n$-kets from peat forming plants (Nichols and Huang, 2007, Ortiz et al., 2011), the inference for the dominant source of the Mfabeni $n$-kets from microbial alteration of $n$-alks and $n$-FAs is further supported by significant positive trends between the $n$-kets and their corresponding $n$-alk and $n+1$-FA precursor ratios (Fig. 4; Table 1). 
Because the dominant control on peat accumulation in the sub-tropics is the extent of waterlogging events (Couwenberg et al., 2010), we surmise that, during times of increased waterlogging in the fen, the dominant sources of $\mathrm{C}_{23}$ and $\mathrm{C}_{25} n$-kets were aquatic plant $n$-alk and $n$-FA precursors. However, the $n$ - $\mathrm{C}_{23}$ ket/alk and $n$ - $\mathrm{C}_{25} \mathrm{ket} / \mathrm{alk}$ ratios display significant negative correlations $(\mathrm{r}=-034, \mathrm{P}=0.01, \mathrm{df}=34$ and $\mathrm{r}=-0.40$, respectively) with the $n$-alk aquatic plant proxy ( $\mathrm{P}_{\text {aq }}$; Fig. 4, Table 1$)$, suggesting an additional process that controlled the formation of $n$-kets from their $n$-alk and $n$-FA precursors. Therefore, we surmise that due to the limited oxygen availability during extensive waterlogging events, microbial conversion of the precursor $n$-alks and $n$-FAs to $n$-kets was retarded (Bardgett et al., 2008), which would result in a negative statistical relation between $n-\mathrm{C}_{23}$ and $n-\mathrm{C}_{25}$ ket/ alk and $\mathrm{P}_{\text {aq }}$ proxies. Consistent with this hypothesis, the $\mathrm{ACL}_{\mathrm{ket}}$ values (Fig. 4, Table 1) also show a negative correlation with $\mathrm{P}_{\mathrm{aq}}$ $(\mathrm{r}=-0.43, \mathrm{P}=0.01, \mathrm{df}=34)$, reinforcing the idea that when aquatic plant input increased due to increased water level in the basin, the predominant $n$-alks available for conversion to their corresponding $n$-kets were those of mid-chain length compounds prevalent in aquatic plants (Ficken at al., 2000; Baker et al., 2016), albeit at a slower rate due to anoxic conditions. Zheng et al. (2011a) concluded the higher ACLket values recorded drier periods in the Hani mire, which they inferred from elevated ACLket and

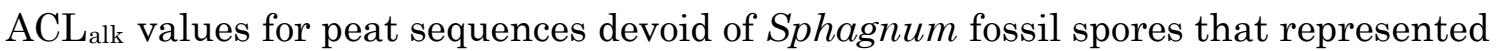
lower water levels in the Hani basin. During periods of decreased water levels in the Mfabeni, the plant communities would have been dominated by emersed (sedges) and terrestrial (grasses) plants that are characterised by long-chain lipids $\left(\mathrm{C}_{27}-\mathrm{C}_{33}\right.$; Meyers and Ishiwatari, 1993) and therefore, $\mathrm{C}_{29}$ ket / $\mathrm{C}_{30} \mathrm{FAs}, \mathrm{C}_{31}$ ket / $\mathrm{C}_{32} \mathrm{FAs}$ and $\mathrm{C}_{31}$ ket/C $\mathrm{C}_{31}$ alks ratios (Fig. 4), are expected to be the most indicative proxies during these periods. The palaeoenvironmental controls on the long chain ket/alk precursor ratios $(n-$ $\mathrm{C}_{27}$ to $n$ - $\mathrm{C}_{31}$ ) is less clear as they do not exhibit correlations with the OM sources or bulk 
geochemical proxies discussed by Baker et al. $(2014,2016)$. Nonetheless, they do trend similarly to the mid-chain length ket/alk ratios ( $n$ - $\mathrm{C}_{23}$ ket/alk and $n$ - $\mathrm{C}_{25}$ ket/alk; Table 1$)$, and since we have established that low $n-\mathrm{C}_{23}$ and $n-\mathrm{C}_{25} \mathrm{ket} /$ precursor values were due to increased waterlogging and slowdown in microbial activity as a result of the ensuing anoxic conditions in the basin, it leads us to infer that the longer chained $n$-kets / precursor ratios were also primarily influenced by water level fluctuation in the Mfabeni record. This assumption is corroborated by the biomarker study in Baker et al. (2016), that concluded plant physiology in the peat basin was dominated by water level fluctuations. On the other hand, Baker et al. (2016) found that even though relatively subdued temperature changes where experienced in the Mfabeni fen, relative to higher latitudes (Finch and Hill, 2008), the sat/unsatFA microbial activity proxy in Core SL6 exhibited a temperature influence. This finding leads us to consider that, even though the $n$-ket proxies appear to be influenced predominantly by water level in the basin, when temperature fluctuated to extreme levels relative to the average conditions in the Mfabeni basin, the $n$-ket ratio could also have been influenced by temperature. Consequently, we use the $n$-ket suite of proxies to directly link higher $n$-ket $/ n$-alk or $n$ FA precursor ratios to decreased waterlogging in the fen, which points to elevated microbial oxidation of $\mathrm{OM}$ occurring in the corresponding peat layer, and vice versa, with temperature as a secondary control.

\subsection{Mid-chain $n$-ket / precursor proxies}

During periods of greater waterlogging as indicated by $>0.4 \mathrm{P}_{\mathrm{aq}}$ and elevated TOC concentration (Fig. 4), we argue that the predominant input of $n$-alks (and $n$-FAs) would have been mid-chain length monomers from submerged plants, and consequently the $n$ $\mathrm{C}_{23}$ ket/ $n$ - $\mathrm{C}_{23}$ alk and $n$ - $\mathrm{C}_{25} \mathrm{ket} / n-\mathrm{C}_{25}$ alk ratios would be the best indicator of palaeoenvironmental conditions during these periods. The negative correlation between 
aquatic plant $n$-alks and $n$-FAs due to anoxic conditions during protracted waterlogging events. For example, during the A2 warming event (ca. 44.5 cal kyr BP and Heinrich 5; H5) the Mfabeni proxies record a period of increased water level in the basin (high \%TOC, Fig. 4) with a dominant submerged macrophyte population (>0.4 $\mathrm{P}_{\mathrm{aq}}$; Fig. 4) and a replacement of $\mathrm{C}_{3}$ riparian/swamp forests by $\mathrm{C}_{4}$ wetland sedge with aquatic vegetation (Fig. 5) because of increased regional precipitation and warmer temperatures (Baker et al., 2017). Similarly, after 30.6 cal kyr BP, TOC concentration steadily increases, with a shift to higher, albeit fluctuating proportions (Fig. 4) of aquatic plant input, increased sat/unsatFA and CPIFA values (Fig. 5, Baker et al., 2016), signalling elevated precipitation and warmer temperatures. However, the $n-\mathrm{C}_{23}$ ket and $n$ - $\mathrm{C}_{25}$ ket/alk ratios remained relatively low but stable (Fig. 4), reinforcing the notion of an overall increased waterlogging that preserved the $n$-alk OM source derived from a predominantly aquatic plant input. Between ca. 26 and 23 cal kyr $\mathrm{BP}$, the $\mathrm{P}_{\mathrm{aq}}$ values record a dominant aquatic plant signal $(>0.60)$, concordant with elevated TOC concentration, but subdued $n$ - $\mathrm{C}_{23}, n$ $\mathrm{C}_{25}$ ket/alk ratios, and decreased $n-\mathrm{C}_{25} \mathrm{ket} / n$ - $\mathrm{C}_{26} \mathrm{FA}$ ratios (Fig. 4). These trends suggest a period of high moisture availability coeval with lower temperatures that prevailed at the time of deposition. This interpretation is supported by the sat/unsatFA proxy (Fig. 5) that displays below average values, which Baker et al. (2016) inferred as evidence of a period of relatively cool and moist conditions. 

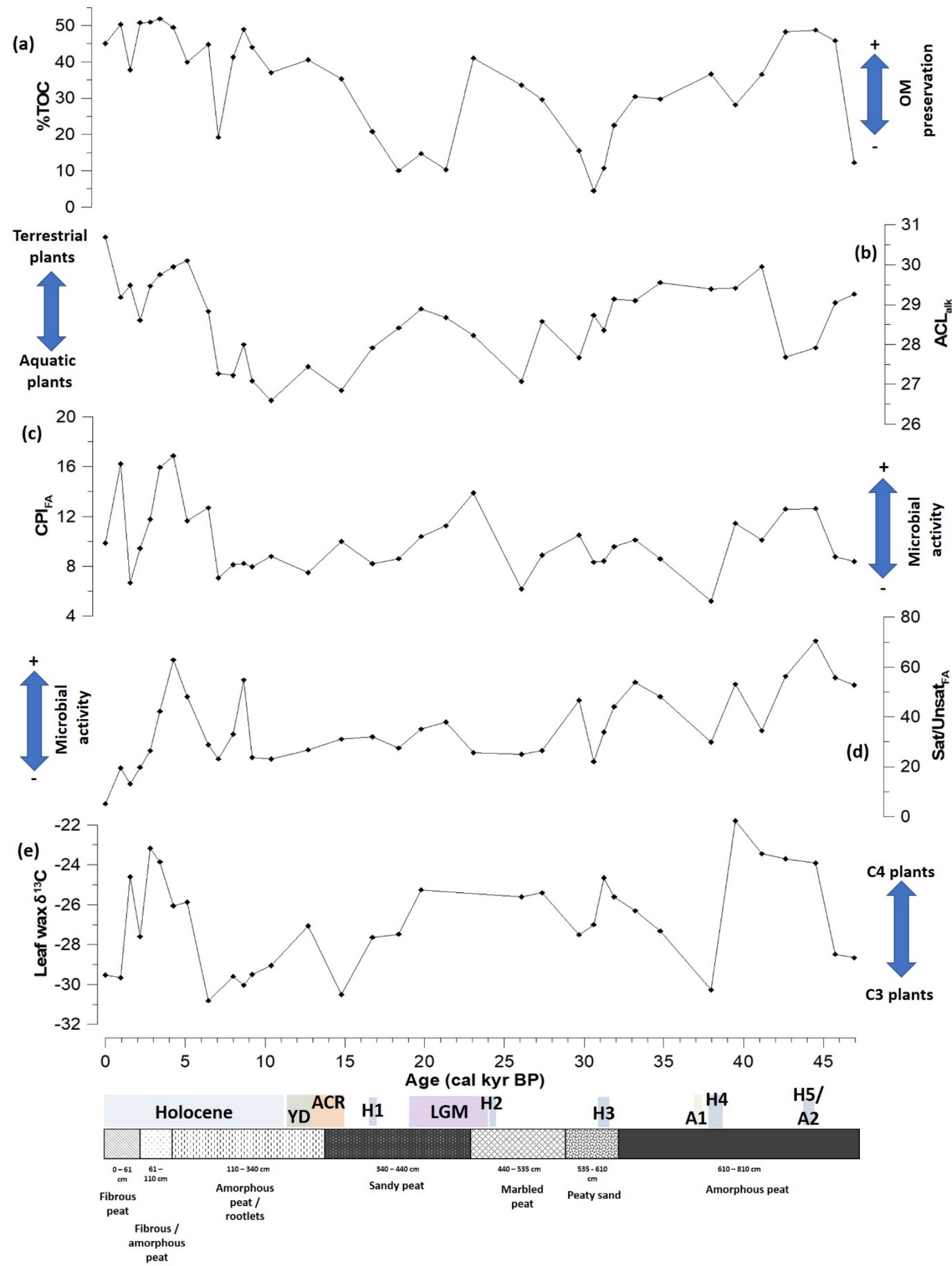

Figure 5: Biomarker and leaf wax $\delta^{13} \mathrm{C}$ proxies from the Mfabeni record. (a) TOC concentrations (Baker et al., 2014), (b) $n$-alkane average chain lengths (ACLalk, Baker et al., 2016), (c) $n$-alkanoic acid carbon chain lengths (CPI ${ }_{\mathrm{FA}}$, Baker et al., 2016), (d) $n$-alkanoic acid saturated / unsaturated chains (sat/unsat FA $_{\text {, Baker et }}$ al., 2016), (e) compound specific leaf wax $\delta^{13} \mathrm{C}$ isotopes (Baker et al., 2017). 
361 At the start of the deglacial period (ca. 19 - 10.5 cal kyr BP), TOC concentration remains

362 low until ca. 16.7 cal kyr BP. Thereafter, the biomarker proxies record an increase in aquatic plant input $\left(\mathrm{P}_{\mathrm{aq}}\right)$ and an overall increase in TOC (Fig. 4), but low microbial activity (sat/unsatFA and CPI FA remain relatively high, Fig. 5, Baker et al., 2016) up to the early Holocene. Baker et al. (2016) deduced that this was due to a steady increase in water waterlogging within the peat basin, but stagnant ambient air temperature during deglaciation. This interpretation is supported by the $n$ - $\mathrm{C}_{25}$ ket, $n$ - $\mathrm{C}_{23}$ ket/alk and $n$ $\mathrm{C}_{25} \mathrm{ket} / n-\mathrm{C}_{26} \mathrm{FA}$ ratios, that show low values throughout the deglacial period, suggesting slow microbial activity due to overall increased water level and low ambient air temperature.

During the early Holocene, core SL6 recorded a predominant submerged macrophyte input (>0.4 $\mathrm{P}_{\mathrm{aq}}$ ), with low $n$ - $\mathrm{C}_{23}$ and $n$ - $\mathrm{C}_{25} \mathrm{ket} /$ alk proxy values until ca. $7.1 \mathrm{cal} \mathrm{kyr} \mathrm{BP}$ (Fig. 4), suggesting a cool and moist early Holocene epoch. The biomarker study of the core similarly displayed subdued CPI FA and ACLalc ratios (Fig. 5), concordant with elevated TOC concentration (Baker et al., 2016), reinforcing the cool and moist conditions implied by the $n$-ket proxies. At ca. 2.2 cal kyr BP, an abrupt increase in $\mathrm{P}_{\mathrm{aq}}$ values occurs, corresponding to a decrease in $n$ - $\mathrm{C}_{23}$ ket and $n$ - $\mathrm{C}_{25}$ ket/alk (Fig. 4),

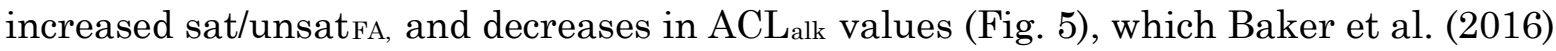
concluded was due to a rapid increase in water level, aquatic plant input, and elevated air temperature. This period of increased waterlogging suggested by the biomarker proxies could arguably have resulted in a protracted anoxic horizon that led to a significant decrease in microbial alteration of mid-chain aquatic plant $\mathrm{n}$-alks, recorded by the ensuing large decline in $n$ - $\mathrm{C}_{23}$ ket/alk and to a lesser degree $n$ - $\mathrm{C}_{25} \mathrm{ket} / \mathrm{alk}$. 
Under dry conditions with decreased waterlogging when emersed and terrestrial plants proliferated, the most indicative palaeoenvironment proxies are likely to be the long chain $n$-kets / precursor ratios. During the H4 (ca. 38 cal kyr BP) and A1 (ca. 37 cal kyr $\mathrm{BP}$ ) events, a transition to $\mathrm{C}_{3}$ arboreal forests occurred because of decreased water levels in the basin (Fig. 5, Baker et al., 2017). This change was recorded by a terrestrial/emersed OM plant signature $\left(<0.2 \mathrm{P}_{\text {aq }}\right)$ that was coeval with decreased \%TOC (Fig. 4), suggesting dry conditions in the basin. Because of the dominance of longchain lipids in terrestrial and emersed plants, the significant increase in both the $n$ - $\mathrm{C}_{31}$ ket/alk and $n-\mathrm{C}_{31}$ ket/FA proxies (Fig. 4) during and after the A1 event implies an increase in production of long-chain $n$-kets from their corresponding precursors during this period of decreased water level, and poor preservation of organic matter. The \%TOC signal subsequently decreases to the core minimum $(4.5 \%$; 30.6 cal kyr BP; H3; Baker et al., 2014) that coincides with an increase in sandy peat deposition and low sat/unsatFA (Fig. 5, Baker et al., 2016), with depressed $n$ - $\mathrm{C}_{31}$ ket/alk and $n$-C $\mathrm{C}_{31} \mathrm{ket} / \mathrm{FA}$ values (Fig. 4) up to ca. 30.6 cal kyr BP, signifying cool and dry conditions.

During the peak of the Last Glacial Maximum (LGM, ca. 23 - 19 cal kyr BP) the Mfabeni archive recorded a change to $\mathrm{C}_{3}$ temperate grasslands (Fig. 5) and an exclusion of wetland aquatic plants (Baker et al., 2017), concordant with a sharp decline in TOC concentration (Fig. 4) and below average sat/unsatFA values (Fig. 5, Baker et al., 2016), implying minimal waterlogging and a shift to cool and dry glacial conditions. Following the LGM, the deglacial period representing the transition from full glacial to interglacial conditions of the Holocene saw a gradual increase in temperatures and water levels. However, Baker et al. (2016) found that the Antarctic Cold Reversal (ACR; ca. 14.5 12.9 cal kyr BP) encouraged an increase in emersed and terrestrial plant input (decreased $\mathrm{P}_{\mathrm{aq}}$ ) in response to a brief period of dry conditions. The $n$-ket proxies support 
this implication of drier ACR conditions by exhibiting a discernible increase in $n$ $\mathrm{C}_{27} \mathrm{ket} / n-\mathrm{C}_{28} \mathrm{FA}$ and $n-\mathrm{C}_{29} \mathrm{ket} / n-\mathrm{C}_{30} \mathrm{FA}$ ratios (Fig. 4).

During the Holocene Altithermal (at 8.7 al kyr BP), the sat/unsatFA proxy increases sharply (Fig. 5, Baker et al., 2016), coinciding with an increase in $n$ - $\mathrm{C}_{31}$ ket/FA and $n$ $\mathrm{C}_{31}$ ket/alk and a drop in $\mathrm{P}_{\mathrm{aq}}$ (Fig. 4), suggesting elevated temperatures and inputs from emersed plants. Thereafter, a dry event is recorded at ca. 7.1 cal kyr BP, whereby TOC concentration decreases to its lowest level during the Holocene (19.2\%; Baker et al., 2014). Subsequently, the proxy for OM source record a predominant terrestrial/emersed plant origin ( $\mathrm{P}_{\mathrm{aq}}<0.15$; Fig. 4) indicated by elevated but fluctuating mid- and long-chain $n$-ket/alk, $n$-ket/FA ratios (Fig. 4) and increased sat/unsatFA values until 2.2 cal kyr BP (Fig. 5, Baker et al., 2016). These trends suggest decreased water levels, but elevated temperature. Baker et al. (2016) concluded that the warmer post-glacial conditions during the mid-Holocene resulted in higher NPP of vascular plant growth in the basin that resulted in peat accumulating without the usual permanent waterlogging owing to high sedimentation rates and more recalcitrant OM sources.

After the brief period of waterlogging at ca. 2.2 cal kyr BP, core SL6 recorded an increase in the proportions of OM input from emersed and terrestrial plants and a decrease of input from aquatic plants $\left(0.3-0.06 \mathrm{P}_{\mathrm{aq}}\right.$; Fig. 4). This source change was also indicated by low long-chain ket/FA and ket/alk ratios and fluctuating TOC concentration (Fig. 4). These changes signify an overall drying trend with fluctuating precipitation (Baker et al., 2017) that has persisted until today. This inference is supported by a transition to grassland dominated habitats recorded in the Mfabeni by Finch and Hill (2008) after ca. $2.2 \mathrm{k}$ cal yr BP. 
Because fluctuations in basin hydrology can cause changes in plant assemblages that produce distinctive leaf wax lipids (Cranwell, 1974, Schwark et al., 2002), the ACL biomarker proxy has been used to delineate available moisture in peat deposits (Schefuß et al., 2003, Zhou et al., 2005, 2010, Baker et al., 2016). ACLket values in core SL6 correlate negatively with $\mathrm{P}_{\mathrm{aq}}$ (Table 1, Fig. 4), suggesting the mid-chain aquatic plant $n$ alk precursors were the predominant source of $n$-kets during periods of high water levels. Alternatively, when water levels were lower and emersed /terrestrial plants proliferated, elevated $\mathrm{ACL}_{\mathrm{ket}}$ values recorded drier conditions.

For instance, during the LGM and early deglacial period (ca. 23 - 15 cal kyr BP), Baker et al. (2017) reported biomarker evidence for dominance of $\mathrm{C}_{3}$ temperate grasslands in the Mfabeni basin to the exclusion of wetland aquatic plants, concordant with a sharp decline in TOC concentration (Baker et al., 2014) and below average sat/unsatFA values (Fig. 5, Baker et al., 2016). These parameters imply minimal waterlogging and a shift towards dry glacial conditions. Consistent with this, the ACLket values exhibited a sharp increase during the same period, supporting the implied change to dominant terrigenous plant input (Fig. 4).

Alternatively, under interglacial conditions during the mid-Holocene (ca. $6.5-2.5$ cal kyr BP) directly after the ca. 7.1 cal kyr BP drying event, where TOC concentration drops to its lowest level during the Holocene (19.2\%; Baker et al., 2014), the sat/unsatFA proxy exhibits a sharp increase (Fig. 5, Baker et al., 2016), corresponding to a drop in $\mathrm{P}_{\mathrm{aq}}$, and an increase in \%TOC and $\mathrm{ACL}_{\mathrm{ket}}$ (Fig. 4). The OM source proxies agree with this observation by recording a predominant terrestrial/emersed plant origin $\left(\mathrm{P}_{\mathrm{aq}}<0.15\right.$; ACLket $_{2} 28$ ); correlating to elevated but fluctuating mid- and long-chain $n$-ket/alk and $n$ ket/FA ratios (Fig. 4). These observations are opposite to what was been previously recorded under glacial conditions in the Mfabeni peat archive, where elevated TOC concentrations indicated elevated water levels, as they coincide with increased aquatic 
plant inputs and lower ACL ket (Fig. 4). However, as discussed in section 4.3, Baker et al.

463 (2016), reported an opposite trend between the $n$-alk carbon preference index (CPI $\left.{ }_{\text {alk }}\right)$

and TOC concentration during the Holocene (Fig. 5). They suggested the high sedimentation rates which accompanied the elevated NPP that was confirmed by the relatively high $\mathrm{C}$ accumulation rates reported by Baker et al. (2014) played a dominant role in peat accumulation, as opposed to waterlogging in the Mfabeni basin during this period in Holocene.

\section{5. $n$-ket palaeoproxy potential}

We argue that the changes in peat plant communities that were driven by fluctuating palaeoenvironmental conditions in the Mfabeni basin dictated the dominant chain length $n$-alks and $n$-FAs available for microbial alteration into the $n$-kets found in the sediment record and therefore, can serve as an OM source proxy. Additionally, since the mid- and long-chain $n$-ket/precursor ratios both exhibited a negative relation with the $\mathrm{P}_{\text {aq }}$ proxy, we concluded that the mid- and long-chain n-ket/precursor ratios are a good indicator of microbial activity during times of aquatic or emersed / terrestrial plant proliferation, each thriving in different palaeohabitats. The opposite trends between the $\mathrm{P}_{\mathrm{aq}}$ and $\mathrm{ACL}_{\mathrm{ket}}$ proxy (Table 1) proved to be a useful additional tool to delineate $\mathrm{OM}$ sources and palaeohydrology. In addition, $\mathrm{ACL}_{\mathrm{ket}}$, can be also be used to reconstruct changes in palaeohydrology and biomarker sources, most appropriately in the Mfabeni fen, where water level fluctuations dominated peat formation under glacial conditions, while high sedimentation rates and recalcitrant $\mathrm{OM}$ sources dictated $\mathrm{C}$ accumulation during much of the Holocene.

By investigating the trends between established Mfabeni bulk geochemical, biomarker and leaf wax ${ }^{13} \mathrm{C}$ isotope data with those of the novel $n$-ket ratios, we find that there is a 
definite potential for these biomarkers to be used as proxies for interpreting palaeoenvironmental conditions. Not only do they seem to indicate the source/precursor relations, but they also give us more insight into OM remineralisation after deposition. Coupled with a good understanding of peat accumulation dynamics, they have shown to be good indicators in the Mfabeni record for delineating palaeoenvironmental conditions with greater confidence within a multiproxy approach.

\section{Conclusions}

Our study shows that $n$-ket biomarker compounds have good potential as a palaeoenvironmental proxy for interpreting past climatic conditions. Their predominant origin was established to be via microbial metabolic alterations of primary $n$-alk and $n$ FA compounds derived from higher plants. Because the Mfabeni fen falls within a subtropical climate, peat accumulation is predominantly controlled by waterlogging events, with temperature playing a secondary role. Consequently, we conclude that the $n$-ket proxies respond predominantly to change in precipitation, with temperature being of secondary importance. By comparing the $n$-ket proxies with published bulk geochemical, $n$-alk, $n$-FA, and $n$-alc biomarker proxies and leaf wax $\delta^{13} \mathrm{C}$ data in conjunction with other climate archives, we established that the $n$-ket biomarkers are sensitive to similar environmental/climatic fluctuations in the Mfabeni fen. However, further research is required to establish the full potential of $n$-ket climate proxies in diverse palaeoclimate archives to assist in clarifying the dominant controls of this ubiquitous biomarker at different latitudes. Our research has reiterated the importance of employing a multi-proxy approach to resolve inconstancies between proxies when attempting to delineate palaeoenvironmental conditions from sedimentary archives. 
A. Clulow assisted with field access and site identification. iSimangaliso Authority and

Ezemvelo KZN Wildlife granted park access and sampling permits. We thank the detailed reviews and comments from Jonathan Nichols, an anonymous reviewer, and Associate Editor Phil Meyers that significantly improved the manuscript. The project was supported through a bilateral funding agreement by the Swedish Research Link-

South Africa program (Grant \# 348-2009-6500). Student support was provided by the

National Research Foundation (Grant \# SFH13082029403) and InKaba yeAfrica. This is an Iphakade publication no. 185 and AEON publication no. 174.

\section{References}

Baas, M., Pancost, R., van Geel, B., Sinninghe-Damsté, J.S., 2000. A comparative study of lipids in Sphagnum species. Organic Geochemistry 31, 535-541.

Bai, Y., Fang, X.M., Wang, Y.L., Kenig, F., Miao, Y.F., Wang, Y.X., 2006. Distribution of aliphatic ketones in Chinese soils: potential environmental implications. Organic Geochemistry 37, 860-869.

Baker, A., Routh, J., Blaauw, M., Roychoudhury, A.N., 2014. Geochemical records of palaeoenvironmental controls on peat forming processes in the Mfabeni peatland, Kwazulu Natal, South Africa since the Late Pleistocene. Palaeogeography, Palaeoclimatology, Palaeoecology 395, 95-106.

Baker, A., Routh, J., Roychoudhury, A.N., 2016. Biomarker records of palaeoenvironmental variations in subtropical southern Africa since the late Pleistocene: evidence from a coastal peatland. Palaeogeography, Palaeoclimatology, Palaeoecology 451, 1-12.

Baker, A., 2016. Bulk geochemical, biomarker and leaf wax isotope records of Mfabeni peatland, KwaZulu Natal, South Africa since the late Pleistocene. PhD thesis, Earth Sciences Department, Stellenbosch University. http://hdl.handle.net/10019.1/98580.

Baker, A., Pedentchouk, N., Routh, J., Roychoudhury, A.N., 2017. Climate variability in Mfabeni peatlands (South Africa) since the Late Pleistocene. Quaternary Science Reviews 160, 57-66. 
Bardgett, R.D., Freeman, C., Ostle, N.J., 2008. Microbial contributions to climate change through carbon cycle feedbacks. The ISME Journal 2, 805-814.

Blaauw, M., Christeny, J.A., 2011. Flexible paleoclimate age-depth models using an autoregressive gamma process. Bayesian Analysis 6, 457-474.

Blunier, T., Chappellaz, J., Schwander, J., DaÈllenbach, A., Stauffer, B., Stocker, T. F., Raynaud, D., Jouzel, J., Clausen, H. B., Hammer, C. U., Johnsen, S. J., 1998. Asynchrony of Antarctic and Greenland climate change during the last glacial period. Nature 394, 739-743.

Botha, G., Porat, N., 2007. Soil chronosequence development in dunes on the southeast African coastal plain, Maputaland, South Africa. Quaternary International 162-163, $111-132$.

Bull, I.D., van Bergen, P.F., Nott, C.J., Poulton, P.R., Evershed, R.P., 2000. Organic geochemical studies of soils from the Rothamsted classical experiments-V. The fate of lipids in different long-term experiments. Organic Geochemistry 31, 389-408.

Chimner, R. A., Ewel, K.C., 2005. A tropical freshwater wetland: II. Production, decomposition, and peat formation. Wetlands Ecology and Management 13, 671-684.

Clulow, A. D., Everson, C.S., Mengistu, M.G., Jarmain, C., Jewitt, G.P.W., Price, J.S., Grundling, P.L., 2012. Measurement and modelling of evaporation from a coastal wetland in Maputaland, South Africa. Hydrology Earth Systems Science 16, 32333247.

Cranwell, P. A., 1974. Monocarboxylic acids in lake sediments: Indicators, derived from terrestrial and aquatic biota, of paleoenvironmental trophic levels. Chemical Geology. $14,1-14$.

Cranwell, P.A., Eglinton, G., Robinson, N., 1987. Lipids of aquatic organisms as potential contributors to lacustrine sediments-II. Organic Geochemistry 11, 513-527.

Couwenberg, J., Dommain, R., Joosten, H., 2010. Greenhouse gas fluxes from tropical peatlands in south-east Asia. Global Change Biology 16, 1715-1732.

Ficken, K.J., Li, B., Swain, D.L., Eglinton, G., 2000. An $n$-alkane proxy for the sedimentary input of submerged / floating freshwater aquatic macrophytes. Organic Geochemistry 31, 745-749. 
Finch, J.M. 2005. Late Quaternary Palaeoenvironments of the Mfabeni Peatland, Northern Kwazulu-Natal: MSc thesis. University of KwaZulu-Natal, Pietermaritzburg.

Finch, J.M., Hill, T.R., 2008. A late Quaternary pollen sequence from Mfabeni Peatland, South Africa: Reconstructing forest history in Maputaland. Quaternary Research 70, $442-450$.

Grundling, P.L. 2001. The Quaternary Peat Deposits of Maputaland, Northern KwaZulu-Natal, South Africa: Categorisation, Chronology and Utilisation. MSc thesis. University of Johannesburg.

Grundling, P.L., Grootjans, A. P., Price, J.S., Ellery, W.N., 2013. Development and persistence of an African mire: How the oldest South African fen has survived in a marginal climate. Catena 110, 176-183.

Hemming, S.R., 2004. Heinrich events: Massive late Pleistocene detritus layers of the North Atlanitc and their global climate imprint. Review of Geophysics 42, 1-43.

Hernandez, M.E., Mead, R., Peralba, M.C., Jaffé, R., 2001. Origin and transport of $n$ alkan-2-ones in a subtropical estuary: potential biomarkers for seagrass-derived organic matter. Organic Geochemistry 32, 21-32.

Huang, Y., Bol, R., Harkness, D.D., Ineson, P., Eglinton, G., 1996. Post-glacial variations in distributions, ${ }^{13} \mathrm{C}$ and ${ }^{14} \mathrm{C}$ contents of aliphatic hydrocarbons and bulk organic matter in three types of British acid upland soils. Organic Geochemistry 24, 273-287.

Jaffé, R., Mead, R., Hernandez, M.E., Peralba, M.C., Ja, R., Diguida, O.A., 2001. Origin and transport of sedimentary organic matter in two subtropical estuaries: a comparative, biomarker-based study. Organic Geochemistry 32, 507-526.

Kelbe, B., Rawlins, B., 1993. Geohydrology of the eastern shores of St Lucia, in: Taylor, R.H. (Ed.), Proceedings of the Workshop on Water Requirements for Lake St Lucia. Department of Environmental Affairs, Pretoria, South Africa, pp. 32-38.

Lehtonen, K., Ketola, M., 1990. Occurrence of long-chain acyclic methyl ketones in Sphagnum and Carex peats of various degrees of humification. Organic Geochemistry $15,275-280$.

Lehtonen, K., Ketola, M., 1993. Solvent-extractable lipids of Sphagnum, Carex, Bryales and Carex-Bryales peats: content and compositional features vs. peat humification. Organic Geochemistry 20, 363-380. 
López-Días, V., Blanco, C. G., Bechtel, A., Püttmann, W., Borrego, A. G., 2013. Different source of n-alkanes and n-alkan-2-ones in a 6000cal. yr BP Sphagnum-rich temperate peat bog (Roñanzas, N Spain). Organic Geochemistry, 57, 7-10.

Mead, R., Xu, Y., Chong, J., Jaffé, R., 2005. Sediment and soil organic matter source assessment as revealed by the molecular distribution and carbon isotopic composition of n-alkanes. Organic Geochemistry 36, 363-370.

Meyers, P.A., Ishiwatari, R., 1993. Lacustrine organic geochemistry: an overview of indicators of organic matter sources and diagenesis in lake sediments. Organic Geochemistry 20, 867-900.

Mucina, L., Adams, J.B., Knevel, I.C., Rutherford, M.C., Powrie, L.W., Bolton, J.J., van der Merwe, J.H., Anderson, R.J., Bornman, T.G., le Roux, A., Janssen, J.A.M., 2006. Coastal vegetation of South Africa. In: Mucina, L., Rutherford, M.C. (Eds.), The Vegetation of South Africa, Lesotho and Swaziland. South African National Biodiversity Institute, Pretoria, pp. 658-696.

Naafs, D.F.W., van Bergen, P.F., Boogert, S.J., de Leeuw, J.W., 2004. Solvent extractable lipids in an acid andic forest soil; variations with depth and season. Soil Biology and Biochemistry 36, 297-308.

Nichols, J.E., Huang, Y.S., 2007. $\mathrm{C}_{23}-\mathrm{C}_{31} n$-alkan-2-ones are biomarkers for the genus Sphagnum in freshwater peatlands. Organic Geochemistry 38, 1972-1976.

Ortiz, J.E., Gallego, J.L.R., Torres, T., Diaz-Bautista, A., Sierra, C., 2010. Palaeoenvironmental reconstruction of Northern Spain during the last 8000 cal yr BP based on the biomarker content of the Ronanzas peat bog (Asturias). Organic Geochemistry 41, 454-466.

Ortiz, J. E., Díaz-Bautista, A., Aldasoro, J. J., Torres, T., Gallego, J. L. R., Moreno, L., \& Estébanez, B., 2011. $n$-Alkan-2-ones in peat-forming plants from the Roñanzas ombrotrophic bog (Asturias, northern Spain). Organic Geochemistry 42, 586-592.

Ramsay, P.J., Cooper, J.A G., 2002. Late Quaternary Sea-Level Change in South Africa. Quaternary Research. 57, 82-90.

Porat, N., Botha, G., 2008. The luminescence chronology of dune development on the Maputaland coastal plain, southeast Africa. Quaternary Science Reviews 27, 10241046.

Rieley, J.O., Ahmad-Shah, A-A., and Brady, M.A., 1996. The extent and nature of tropical peat swamps. In: Maltby, E., Immirzi, C.P., and Safford, R.J. (Eds), Tropical Lowland Peatlands of Southeast Asia. IUCN, Gland, Switzerland, pp. 17-53. 
Sageman, B. B., Lyons, T. W., 2003. Geochemistry of fine-grained sediments and sedimentary rocks. In: Mackenzie, F. (Ed.), Treatise on Geochemistry, vol. 7. Elsevier, New York, pp. 115- 158.

Schefuß, E., Ratmeyer, V., Stuut, J.B.W., Jansen, J.H.F., Sinninghe Damsté, J.S., 2003. Carbon isotope analyses of $n$-alkanes in dust from the lower atmosphere over the central eastern Atlantic. Geochimica et Cosmochimica Acta 67, 1757 - 1767.

Schmidt, M.W.I., Torn, M.S., Abiven, S., Dittmar, T., Guggenberger, G., Janssens, I. A., Kleber, M., Kögel-Knabner, I., Lehmann, J., Manning, D. A. C., Nannipieri, P., Rasse, D.P., Weiner, S., Trumbore, S.E., 2011. Persistence of soil organic matter as an ecosystem property. Nature 478, 49-56.

Schwark, L., Zink, K., Lechterbeck, J., 2002. Reconstruction of postglacial to early Holocene vegetation history in terrestrial Central Europe via cuticular lipid biomarkers and pollen records from lake sediments. Geology 30, 463-466.

Smuts, W.J., 1992. Peatlands of the Natal Mire Complex - geomorphology \& characterization. South African Journal of Science 88, 474-83.

Stocker, T.F., 2000. Past and future reorganizations in the climate system. Quaternary Science Reviews 19, 301-319.

Taylor, R., Kelbe, B., Haldorsen, S., Botha, G. A., Wejden, B., Været, L., Simonsen, M.B., 2006a. Groundwater-dependent ecology of the shoreline of the subtropical Lake St Lucia estuary. Environmental Geology 49, 586-600.

Taylor, R., Adams, J.B., Haldorsen, S., 2006b. Primary habitats of the St Lucia Estuarine System, South Africa, and their responses to mouth management. African Journal of Aquatic Science 31, 31-41.

van Bergen, P.F., Nott, C.J., Bull, I.D., Poulton, P.R., Evershed, R.P., 1998. Organic geochemical studies of soils from the Rothamsted classical experiments-IV. Preliminary results from a study of the effect of soil $\mathrm{pH}$ on organic matter decay. Organic Geochemistry 29, 1779-1795.

Venter, C.E., 2003. Vegetation Ecology of Mfabeni Peat Wwamp, St Lucia, KwaZuluNatal. MSc thesis, Botany Department, University of Pretoria. http://repository.up.ac.za/handle/2263/24480.

Volkman, J.K., Farrington, J.W., Gagosian, R.B., Wakeham, S.G., 1983. Lipid composition of coastal sediments from the Peru upwelling region. In Bjorøy,M., et al. (Eds.), Advances in Organic Geochemistry 1981. Wiley, Chichester, pp.228-240. 
Wakeham, S.G., Peterson, M.L., Hedges, J.I., Lee, C., 2002. Lipid biomarker fluxes in the Arabian Sea, with a comparison to the equatorial Pacific Ocean. Deep-Sea Research Part II 49, 2265-2301.

Wenchuan, Q., Dickman, M., Wang, S., Wu, R., Zhang, P., Chen, J., 1999. Evidence for an aquatic plant origin of ketones found in Taihu Lake sediments. Hydrobiologia, 397, 149-154.

Xie, S., Liang, B., Gu, Y.S., Yang, H., 2008. Distributions of $n$-alkan-2-ones in Quaternary paleosols indicative of paleoclimate changes. Acta Palaontologica Sinica 47, 273-278 (in Chinese).

Zheng, Y., Zhou, W., Liu, X., Zhang, C. L., 2011a. n-Alkan-2-one distributions in a northeastern China peat core spanning the last 16kyr. Organic Geochemistry 42, $25-30$.

Zheng, Y., Zhou, W., Meyers, P. A., 2011b. Proxy value of $n$-alkan-2-ones in the Hongyuan peat sequence to reconstruct Holocene climate changes on the eastern margin of the Tibetan Plateau. Chemical Geology 288, 97-104.

Zhou, W., Xie, S., Meyers, P. A., Zheng, Y., 2005. Reconstruction of late glacial and Holocene climate evolution in southern China from geolipids and pollen in the Dingnan peat sequence. Organic Geochemistry 36, 1272-1284.

Zhou, W., Zheng, Y., Meyers, P. A., Jull, a. J.T., Xie, S., 2010. Postglacial climate-change record in biomarker lipid compositions of the Hani peat sequence, Northeastern China. Earth Planetary Science Letters 294, 37-46. 